University of Nebraska - Lincoln

DigitalCommons@University of Nebraska - Lincoln

Agronomy \& Horticulture -- Faculty Publications

Agronomy and Horticulture Department

4-1947

\title{
A Method Of Measuring Vigor Of Range Grasses
}

J. E. Weaver

University of Nebraska-Lincoln

Follow this and additional works at: https://digitalcommons.unl.edu/agronomyfacpub

Part of the Plant Sciences Commons

Weaver, J. E., "A Method Of Measuring Vigor Of Range Grasses" (1947). Agronomy \& Horticulture -Faculty Publications. 486.

https://digitalcommons.unl.edu/agronomyfacpub/486

This Article is brought to you for free and open access by the Agronomy and Horticulture Department at DigitalCommons@University of Nebraska - Lincoln. It has been accepted for inclusion in Agronomy \& Horticulture -Faculty Publications by an authorized administrator of DigitalCommons@University of Nebraska - Lincoln. 


\title{
A METHOD OF MEASURING VIGOR OF RANGE GRASSES ${ }^{1}$
}

\author{
J. E. Weaver and R. W. Darland
}

\section{INTRODUCTION}

After several years of intensive study of midwestern prairies, their degeneration under grazing was given careful consideration (Weaver and Fitzpatrick, '32, '34; Weaver and Hansen, '41). It was ascertained that the intelligent use or careless abuse of these grasslands had resulted in pastures and ranges which could logically be grouped into four classes. These were excellent, good, medium, and poor. The first consisted almost entirely of climax grasses and an abundance of nutritious forbs which, as is almost universally found, were of the highest grazing value (Bews, '29:298). In good pastures many of these persisted, but there was a strong trend toward loss of vigor and decrease in abundance of the best grasses and forbs. About half of the vegetation consisted of the less productive Kentucky bluegrass (Poa pratensis) ${ }^{2}$ or short grasses. In pastures of medium grade, climax grasses and the most palatable forbs had all but disappeared. Here bluegrass, blue grama (Bouteloua gracilis) or buffalo grass (Buchloe dactyloides) were the dominants. Usually bluegrass alone was in control east of the Missouri river and the short grasses westward, but in the transitional area it was not unusual for both types to occur in alternes. Poor pastures were characterized by broken cover, more or less isolated patches of bluegrass or short grasses, much bare soil or soil supporting a stand of various, mostly annual, weeds. Since the great drought, medium and poor pastures of sand dropseed (Sporobolus cryptandrus) and western wheat grass (Agropyron smithii) also occur.

Similar classification of pastures have now been made in widely separated grass-

\footnotetext{
${ }^{1}$ Contribution from the Department of Botany, University of Nebraska, No. 151.

2 Nomenclature is according to Hitchcock's Manual of the Grasses of the United States.
}

land areas (Costello and Turner, '44; Humphrey and Lister, '41; Renner and Johnson, ' 42 ; and numerous mimeographed articles by U. S. Forest Service and Soil Conservation Service). Such classification is a valuable aid to the range examiner, range conservationist, or county agent in pointing out definitely to the rancher or farmer the grade and condition of his range. He then may explain how it may be kept in the excellent or good class or if degenerated to a medium or poor type how it may be brought back to its former good or excellent condition. The several characteristics or indicators of each grade of pasture are well known to range technicians. They are understandable when explained to an intelligent layman. Once comprehended, the actual present state of the pasture in relation to what it could and should be stands out clearly. This is a valuable aid in promoting proper range and pasture management.

Pastures of low grade, which result from too early use, too frequent use, and too close removal of the forage (but also sometimes from continued drought), are usually by far the most abundant. The rate at which many excellent native pastures have deteriorated into poor ones is alarming. Degeneration from virgin prairie to poor pastures has repeatedly been observed to occur within a period of 3 to 4 years. Much of this overstocking and continuous grazing is unintentional on the part of the farmer or range operator, simply because he is unfamiliar with the fundamental physiological activities of plants. If the average stockman notices the "eaten out" bunches and general reduced vigor of plants at all, he thinks of it as a normal result of grazing. $\mathrm{He}$ does not realize that health and vigor of plants are almost synonymous with forage production. He does not know how to determine whether the vegetation will 
continue to thrive and maintain high forage production or weaken and die and be replaced by competing weeds and inferior grasses.

It is well to tactfully inform the rancher or farmer that his range or pasture is of poor or medium grade. But it is still better to demonstrate to him before such degeneration occurs that loss of plant vigor is a fair warning that such change is imminent. The most important indicators among plants as to the condition of the range are composition, density, and vigor of the vegetation. Composition is the variety or mixture of species present. Excellent and good ranges present a mixture of many palatable perennial grasses and forbs, mostly of the kinds found in ungrazed, native grassland. Density is the amount of soil covered by the vegetation. Plant vigor is indicated in many ways. It is commonly shown above ground by the size of bunches or clumps and especially the number of stems, whether they are few and scattered or many. The absence or presence of dead centers is also important, as well as the partial or complete death of bunches or sodded areas. The age classes present are of great importance. If there are small clumps as well as seedlings and clumps of intermediate size in addition to the old, mature ones, vigor of the plants is good and the continuation of their kind is assured. Prompt renewal of growth in spring or after grazing, when conditions for growth are favorable, is a positive expression of vigor and denotes a supply of accumulated food in crown or roots and usually a good root system as well. Good height growth, abundance of foliage, and prompt production of flower stalks at the proper season all indicate vigor. Most of these criteria are integrated in high forage yield.

The degree of decreased vigor in many perennial grasses is most readily recognized where it is possible to actually compare average bunches or sodded areas from different pastures. Samples from an overgrazed pasture should be com- pared with those from one moderately grazed or, better, both of these with similar samples from pastures or protected areas that have remained ungrazed for a few years. In an experiment near Lincoln, Nebraska, for example, grasses were measured on June 13,1940, in a series of three, long, adjacent, parallel experimental plots. These plots were portions of a 25-year-old bluestem (Andropogon) pasture. One had been protected from grazing only since March, 1940; the second since March, 1939; and the third since early spring of 1937 . Representative bunches as regards size, height of grass, and density of the crown were selected after a series of measurements to ascertain the average condition in each plot. These are shown in figure 1 . The plot with the poorest grass had been grazed the preceding year. Only 2.5 grams of forage were produced by the weakened bunch from this plot. The second bunch, protected one year and until June 13 of the second year, had partially regained its vigor and produced 11 grams of forage. The third bunch, which had been protected three years and until June of the fourth year had apparently fully recovered its vigor and yielded 40 grams. Loss of vigor may occur slowly with long periods of moderate grazing or very rapidly under intensive grazing as is shown in the following experiments.

\section{Materials and Methods}

Several years ago it was learned that sods or bunches of grass transplanted into large containers in June, and clipped fortnightly, showed in autumn much reduced root systems compared with similar sods where the grass was unclipped (Biswell and Weaver, '33). Root systems of the controls were extensive, large volumes of loam soil were used, and the separation of the roots from the soil was a tedious and prolonged procedure. The effects of the reduced vigor of the plants because of close clipping to simulate grazing were so noticeably reflected in the poor root system that similar experiments have been 


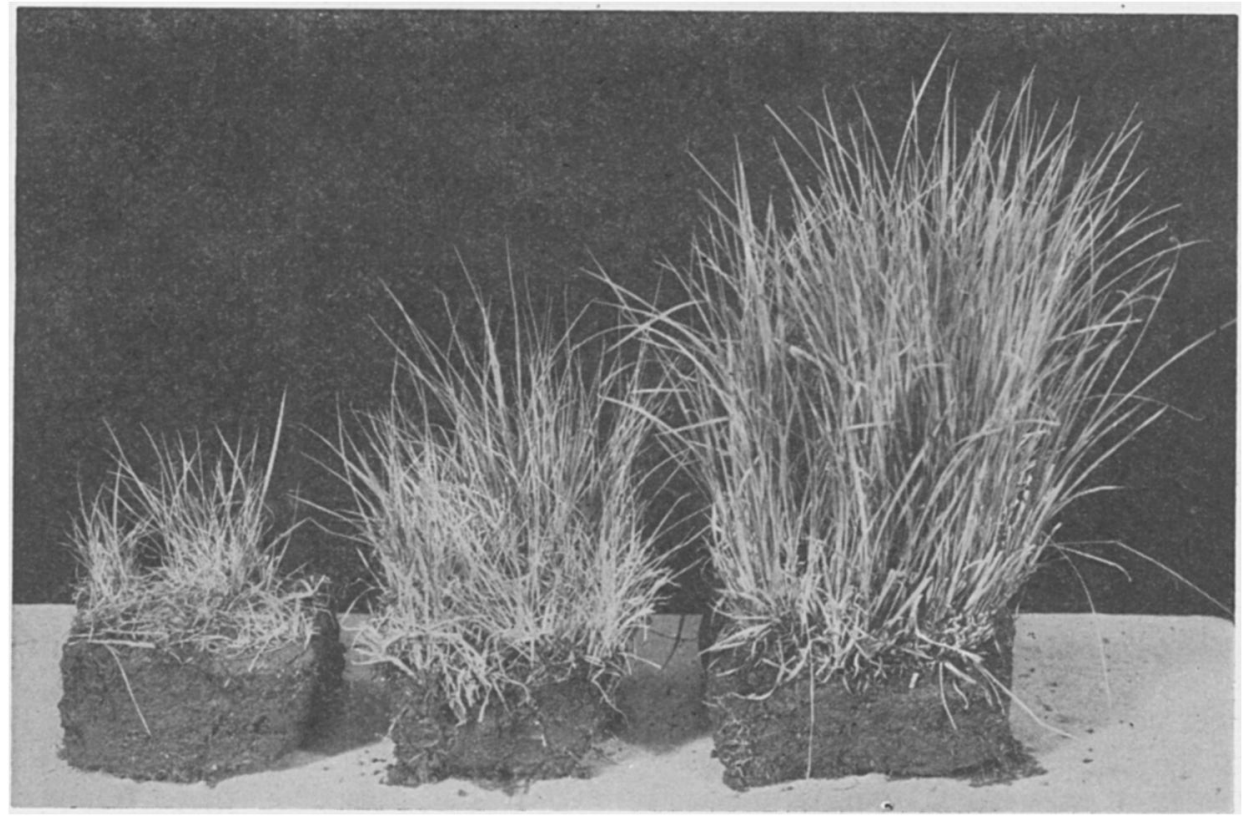

FIG. 1. Bunches of little bluestem (Andropogon scoparius) selected on June 13, 1940, for average size and density of crown. The bunches are from closely adjacent portions of an old pasture protected from grazing (left) since March, 1940, (center) since March, 1939, and (right) since early spring of 1937.

used since in our classes in plant ecology. Recently these have been much improved and simplified. Since these modified experiments were the forerunners of the present research work, they will be described briefly.

Wooden boxes $10 \times 10$ inches in inside dimensions and 24 inches deep were constructed of seven-eighths inch cypress. They were lined with galvanized iron. One side was held in place by two inchwide bands of iron fastened with bolts. Screened loam soil was thoroughly mixed with one-third sand, brought to a water content favorable for growth, and placed in the boxes where it was compacted not by tamping but merely by repeated jolting. Pairs of blocks of sod or bunches of various native grasses were obtained from the prairie as soon as the ground thawed in spring. Both the tops and roots were removed and the blocks were trimmed to the same size, usually $8 \times 8$ inches by 4 inches in depth. If the soil was dry, the sods were placed in water until they were thoroughly soaked. The rhizomes in the sods were divided into clones by cutting the sods in half. Then one piece of the first sod of the pair was planted with one piece of the second. The remaining halves were planted together for a control. Bunches were treated in the same manner. Sandy soil was tamped about each sod, the top of which was only slightly lower than the top of the box. The plants were watered when necessary and kept under an environment in the greenhouse favorable to vigorous growth.

Sods of several species were planted in one experiment on March 7. On March 21 the new tops had reached a height of 4 to 5 inches and could have been grazed. One lot of each was clipped at a height of 2 inches and this was repeated every week thereafter for a period of 4 weeks. The last clipping was on April 11. A week later the pairs of boxes were tilted back from the vertical, the side of the box re- 


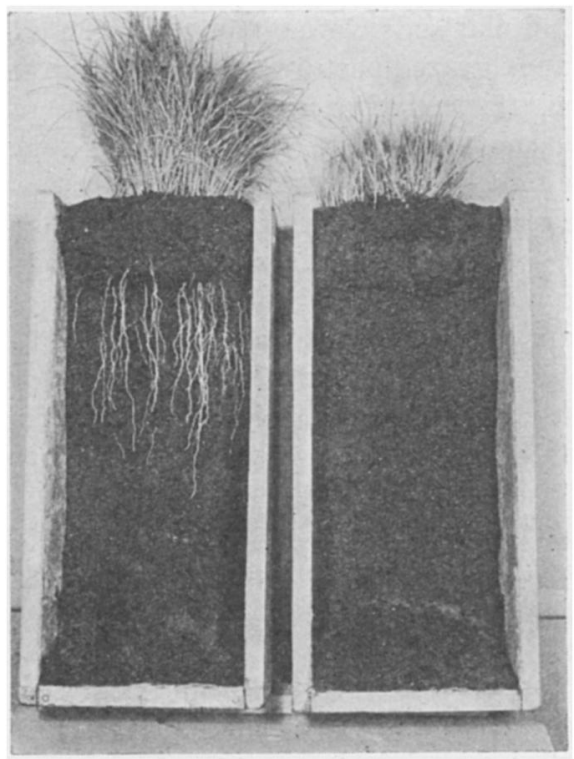

FIG. 2. Growth of tops and roots from similar vigorous bunches of little bluestem 42 days after transplanting the sod blocks. Less than half of the root system is exposed. The control (left) had a total of 150 roots extending below the sod but the plants (right) clipped 4 times had only 3 .

moved, and a part of the soil was washed away by applying water with a hose (fig. 2 ). The control of little bluestem ( $A n$ dropogon scoparius) upon washing soon revealed many glistening white, new roots below the block of sod. None of these were damaged by the spray of water applied to gently wash away the sandy soil. Conversely, there were no roots exposed on the clipped plants. A few short ones did appear before all the soil was removed. About the blocks of tall dropseed (Sporobolus asper) more soil was removed and about two-thirds of the root systems were exposed (fig. 3). This grass, from a later experiment, is shown here only to illustrate the method.

The new growth of tops and roots of tall panic grass (Panicum virgatum), with all soil removed except that in the original block, is shown in figure 4 . It may be noted that even the delicate tips of these shining white roots remained intact.
These sods (except tall dropseed), like those of big bluestem (Andropogon furcatus) and needle grass (Stipa spartea), received the same treatment at the same times as little bluestem. Data on weight of tops, etc., give the experiment quantitative value (table I).

In these experiments decrease in production of roots was due to too early and too frequent removal of tops. Differences were so pronounced and the decrease in the top growth was so similar to that of grasses continuously overgrazed in range and pasture that this general plan was employed as a method of measuring the vigor of various range grasses.

\section{Vigor in Range Grasses}

Sods of sand dropseed, $7 \times 7$ inches and 4 inches deep, were secured from a pasture in the ecological experimental station 4 miles northwest of Lincoln. One from an exclosure had been ungrazed for 8 years, the other a few yards distant, had been moderately grazed. The soil was a clay loam. At the time of transplanting, March 27, the grass was still

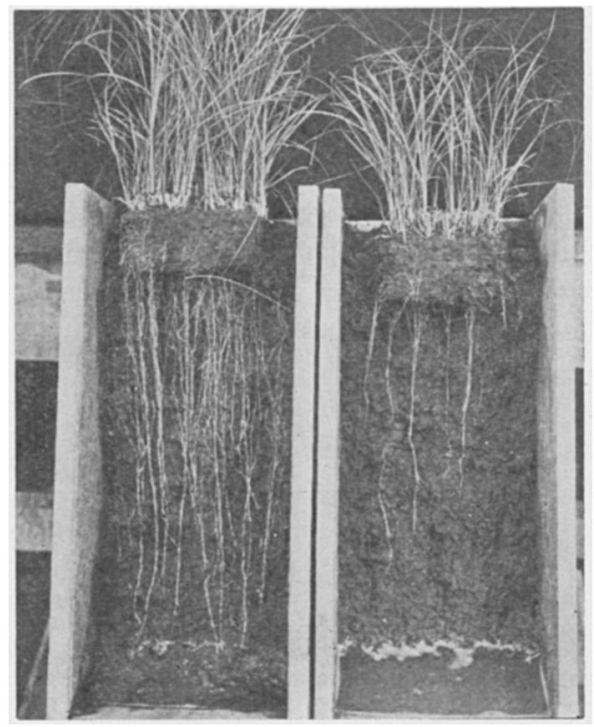

Fig. 3. Transplanted blocks of tall dropseed. One side of the box has been removed and twothirds of the root systems exposed by washing away the soil. 


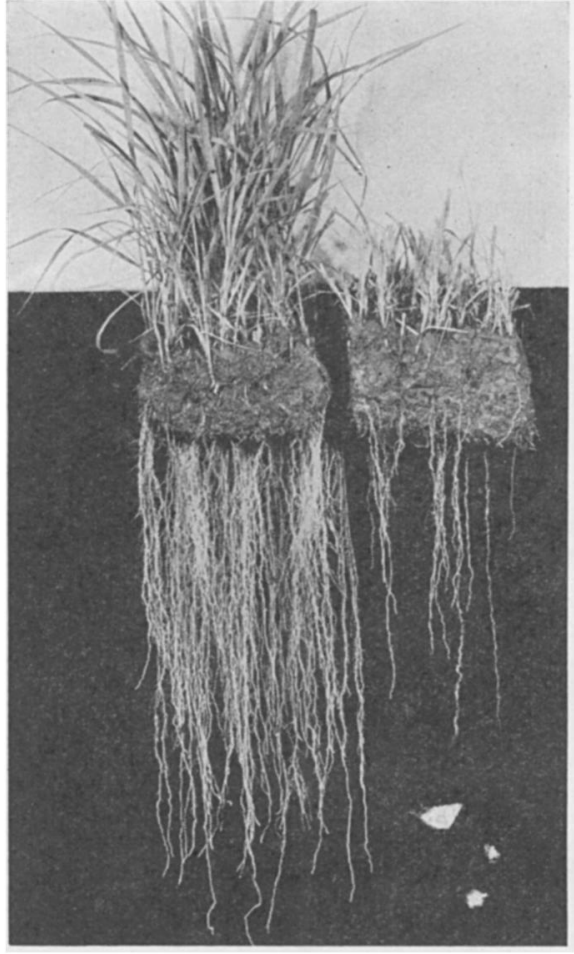

FIG. 4. Entire system of glistening white roots produced by control block of tall panic grass (left) and a portion of the same block of sod from which the tops were removed weekly. Photo 42 days after transplanting.

dormant. On April 30, a difference in height of 3.5 inches and 3 inches in working depth of roots was found. Dry weight of tops of the grazed bunch was 32 per cent less and that of roots 60 per cent less than that of the control (table II).
Similar sods were obtained from a moderately grazed pasture and a closely grazed one, respectively, in mixed prairie near Kearney, Nebraska. The soil was a deep, mellow loess. Grazing in the first pasture was at a height of 2.5 to 3 inches; in the second the foliage was removed to 1.5 inches. The tops, as in all these tests, were removed to the soil surface when the sods were transplanted. About a month after transplanting, height of new foliage was 8 and 6.5 inches and working depth of roots 18 and 11 inches, respectively (fig. 5). The closely grazed plants produced less than a third as much dry weight of foliage, and only about a third as much root material (table II).

Bunches of side-oats grama (Bouteloua curtipendula) in blocks of soil $6 \times 6$ inches and 3 inches deep were obtained, on May 14, from a heavily grazed upland pasture 5 miles west of Lincoln and from an adjacent prairie, respectively. Both were from very fine sandy loam soil. After 45 days, great differences were ascertained. The much less vigorous bunch grew slowly and was 4.5 inches less in height and 6 inches less in working depth of roots than the control. Less than half as much dry weight was produced above ground and only 39 per cent as much root material as in the control (table II).

A second pair of bunches was obtained, on June 10 , from the moderately and closely grazed pastures at Kearney where experimental work is under way and the ranges are under close observation. New

TABLE I. Effect of repeated clipping on similar vigorous sods or bunches of four species of range grasses as expressed in decrease in growth of tops and roots. The length of the root system is that of the new portion below the sod. The maximum depth of roots is shown in parenthesis

\begin{tabular}{|c|c|c|c|c|c|c|c|c|c|c|}
\hline \multirow{2}{*}{ Species } & \multicolumn{2}{|c|}{ Ave. height } & \multicolumn{2}{|c|}{ Dry wt. tops } & \multicolumn{2}{|c|}{ Number roots } & \multicolumn{2}{|c|}{ Ave. depth roots } & \multicolumn{2}{|c|}{ Dry wt. roots } \\
\hline & Control & Clipped & Control & Clipped & Control & Clipped & Control & Clipped & Control & Clipped \\
\hline & \multicolumn{2}{|c|}{ inches } & \multicolumn{2}{|c|}{ grams } & & & \multicolumn{2}{|c|}{ inches } & \multicolumn{2}{|c|}{ grams } \\
\hline Little bluestem & 10 & 4.5 & 15.98 & 2.54 & 150 & 6 & $8(15)$ & $3(5.5)$ & 1.45 & 0.02 \\
\hline Tall panic grass & 13 & 4.0 & 9.37 & 1.71 & 一 & - & $18(24)$ & $7(13.0)$ & 2.95 & 0.16 \\
\hline Big bluestem & 9 & 5.0 & 11.63 & 3.45 & 30 & 15 & $15(21)$ & $8(13.5)$ & 2.27 & 0.37 \\
\hline Needle grass & 14 & 3.5 & 6.77 & 0.99 & 25 & 0 & $12(20)$ & $0(0.0)$ & 0.49 & 0.00 \\
\hline
\end{tabular}


TABLE II. Comparative data on height of foliage, root extent, and dry weight of roots and tops produced by sods or bunches of range grasses. The odd numbers are vigorous or moderately vigorous grasses (as indicated in the text), the even numbers are plants with low vigor

\begin{tabular}{|c|c|c|c|c|c|c|c|c|}
\hline \multirow[b]{2}{*}{ Species } & \multirow[b]{2}{*}{ No. } & \multirow{2}{*}{$\begin{array}{l}\text { Trans- } \\
\text { planted }\end{array}$} & \multirow[b]{2}{*}{ Examined } & \multirow{2}{*}{$\begin{array}{l}\text { Foliage } \\
\text { height }\end{array}$} & \multicolumn{2}{|c|}{ Roots } & \multirow{2}{*}{$\begin{array}{c}\text { Tops, } \\
\text { dry } \\
\text { weight }\end{array}$} & \multirow{2}{*}{$\begin{array}{l}\text { Roots, } \\
\text { dry } \\
\text { weight }\end{array}$} \\
\hline & & & & & $\begin{array}{c}\text { Working } \\
\text { depth }\end{array}$ & $\begin{array}{l}\text { Max. } \\
\text { depth }\end{array}$ & & \\
\hline $\begin{array}{l}\text { Sand dropseed } \\
\text { Sand dropseed }\end{array}$ & $\begin{array}{l}1 \\
2 \\
3 \\
4\end{array}$ & $\begin{array}{l}\text { Mar. } 27 \\
\text { Mar. } 27 \\
\text { June } 10 \\
\text { June } 10\end{array}$ & $\begin{array}{l}\text { Apr. } 30 \\
\text { Apr. } 30 \\
\text { July } 8 \\
\text { July } 8\end{array}$ & $\begin{array}{l}\text { in. } \\
7.5 \\
4.0 \\
8.0 \\
6.5\end{array}$ & $\begin{array}{r}\text { in. } \\
9.0 \\
6.0 \\
18.0 \\
11.0\end{array}$ & $\begin{array}{c}i n . \\
18.0 \\
13.0 \\
24.5 \\
19.5\end{array}$ & $\begin{array}{l}g m . \\
4.82 \\
3.27 \\
7.89 \\
2.32\end{array}$ & $\begin{array}{l}g m . \\
0.25 \\
0.10 \\
0.63 \\
0.22\end{array}$ \\
\hline $\begin{array}{l}\text { Side-oats grama } \\
\text { Side-oats grama }\end{array}$ & $\begin{array}{l}1 \\
2 \\
3 \\
4\end{array}$ & $\begin{array}{l}\text { May } 14 \\
\text { May } 14 \\
\text { June } 10 \\
\text { June } 10\end{array}$ & $\begin{array}{l}\text { June } 28 \\
\text { June } 28 \\
\text { July } 8 \\
\text { July } 8\end{array}$ & $\begin{array}{r}11.5 \\
7.0 \\
7.0 \\
5.0\end{array}$ & $\begin{array}{r}19.0 \\
13.0 \\
16.0 \\
9.5\end{array}$ & $\begin{array}{l}25.0 \\
22.0 \\
21.5 \\
14.0\end{array}$ & $\begin{array}{l}6.66 \\
3.02 \\
2.15 \\
1.02\end{array}$ & $\begin{array}{l}1.58 \\
0.61 \\
0.38 \\
0.16\end{array}$ \\
\hline Scribner's panic grass & $\begin{array}{l}1 \\
2\end{array}$ & $\begin{array}{l}\text { Apr. } 15 \\
\text { Apr. } 15\end{array}$ & $\begin{array}{l}\text { June } 10 \\
\text { June } 10\end{array}$ & $\begin{array}{l}8.5 \\
5.0\end{array}$ & $\begin{array}{r}12.5 \\
9.0\end{array}$ & $\begin{array}{l}19.0 \\
15.5\end{array}$ & $\begin{array}{l}3.55 \\
1.23\end{array}$ & $\begin{array}{l}0.36 \\
0.02\end{array}$ \\
\hline $\begin{array}{l}\text { Buffalo grass } \\
\text { Buffalo grass } \\
\text { Buffalo grass } \\
\text { Buffalo grass }\end{array}$ & $\begin{array}{l}1 \\
2 \\
3 \\
4 \\
5 \\
6 \\
7 \\
8\end{array}$ & $\begin{array}{l}\text { Mar. 27 } \\
\text { Mar. 27 } \\
\text { Apr. 20 } \\
\text { Apr. 20 } \\
\text { June 6 } \\
\text { June 6 } \\
\text { June 10 } \\
\text { June 10 }\end{array}$ & $\begin{array}{l}\text { Apr. } 27 \\
\text { Apr. 27 } \\
\text { June } 3 \\
\text { June } 3 \\
\text { July } 8 \\
\text { July } 8 \\
\text { July } 8 \\
\text { July } 8\end{array}$ & $\begin{array}{l}5.5 \\
3.0 \\
4.5 \\
2.5 \\
8.0 \\
5.5 \\
6.5 \\
5.0\end{array}$ & $\begin{array}{r}12.0 \\
5.0 \\
17.5 \\
8.0 \\
17.5 \\
12.5 \\
18.5 \\
12.5\end{array}$ & $\begin{array}{l}20.0 \\
9.0 \\
- \\
\overline{22.0} \\
16.5 \\
23.0 \\
17.5\end{array}$ & $\begin{array}{l}3.42 \\
1.37 \\
3.10 \\
0.51 \\
5.55 \\
2.66 \\
7.31 \\
3.12\end{array}$ & $\begin{array}{l}0.28 \\
0.19 \\
1.11 \\
0.08 \\
0.58 \\
0.42 \\
1.09 \\
0.23\end{array}$ \\
\hline $\begin{array}{l}\text { Blue grama } \\
\text { Blue grama } \\
\text { Blue grama }\end{array}$ & $\begin{array}{l}1 \\
2 \\
3 \\
4 \\
5 \\
6\end{array}$ & $\begin{array}{l}\text { Mar. 27 } \\
\text { Mar. 27 } \\
\text { Apr. 20 } \\
\text { Apr. 20 } \\
\text { June 10 } \\
\text { June 10 }\end{array}$ & $\begin{array}{l}\text { May } 14 \\
\text { May } 14 \\
\text { June } 3 \\
\text { June } 3 \\
\text { July } 8 \\
\text { July } 8\end{array}$ & $\begin{array}{r}11.0 \\
7.5 \\
6.5 \\
5.0 \\
8.0 \\
6.5\end{array}$ & $\begin{array}{r}14.5 \\
11.0 \\
18.0 \\
9.0 \\
14.0 \\
8.0\end{array}$ & $\begin{array}{l}24.0 \\
17.5 \\
- \\
21.0 \\
12.0\end{array}$ & $\begin{array}{r}11.21 \\
5.71 \\
4.38 \\
0.94 \\
6.76 \\
2.46\end{array}$ & $\begin{array}{l}1.31 \\
0.81 \\
1.29 \\
0.09 \\
0.57 \\
0.11\end{array}$ \\
\hline Big bluestem & $\begin{array}{l}1 \\
2\end{array}$ & $\begin{array}{l}\text { May } 24 \\
\text { May } 24\end{array}$ & $\begin{array}{l}\text { July } 3 \\
\text { July } 3\end{array}$ & $\begin{array}{r}12.0 \\
7.5\end{array}$ & $\begin{array}{r}11.0 \\
8.5\end{array}$ & $\begin{array}{l}21.5 \\
13.0\end{array}$ & $\begin{array}{l}7.11 \\
1.99\end{array}$ & $\begin{array}{l}1.71 \\
0.52\end{array}$ \\
\hline Tall dropseed & $\begin{array}{l}1 \\
2\end{array}$ & $\begin{array}{l}\text { May } 24 \\
\text { May } 24\end{array}$ & $\begin{array}{l}\text { July } 3 \\
\text { July } 3\end{array}$ & $\begin{array}{l}14.5 \\
10.0\end{array}$ & $\begin{array}{r}14.5 \\
8.5\end{array}$ & $\begin{array}{l}22.0 \\
14.0\end{array}$ & $\begin{array}{l}8.12 \\
2.79\end{array}$ & $\begin{array}{l}1.13 \\
0.35\end{array}$ \\
\hline Little bluestem & $\begin{array}{l}1 \\
2\end{array}$ & $\begin{array}{l}\text { May } 14 \\
\text { May } 14\end{array}$ & $\begin{array}{l}\text { June } 28 \\
\text { June } 28\end{array}$ & $\begin{array}{l}9.5 \\
5.0\end{array}$ & $\begin{array}{l}11.0 \\
10.0\end{array}$ & $\begin{array}{l}19.0 \\
13.0\end{array}$ & $\begin{array}{l}5.58 \\
1.44\end{array}$ & $\begin{array}{l}0.80 \\
0.33\end{array}$ \\
\hline
\end{tabular}

tops and roots were permitted to grow for about a month. The overgrazed bunch developed new stems only on its periphery and the roots were correspondingly fewer and shorter (fig. 6 and table II).

Scribner's panic grass (Panicum scribnerianum) was obtained from silt loam soil on the flood plain of Salt Creek near Lincoln. The blocks of soil were $6 \times 6$ inches and 3 inches deep. One had been protected from grazing by the surrounding western wheat grass, the other had been closely grazed for 3 or more years (Darland and Weaver, '45). The plants were only 10 feet apart. After 56 days of growth the new tops of the closely grazed plants were 3.5 inches shorter and 65 per cent less in weight. The working depth of roots was also 3.5 inches shorter and there was very little dry weight produced below the sod (table II).

A block of sod of buffalo grass $7 \times 7$ inches and 4 inches deep was taken on March 27 from a very old pasture on the flood plain of Salt Creek. Here this grass had formed a continuous cover, entirely replacing the former native prairie grasses. A control sod of the same size was ob- 


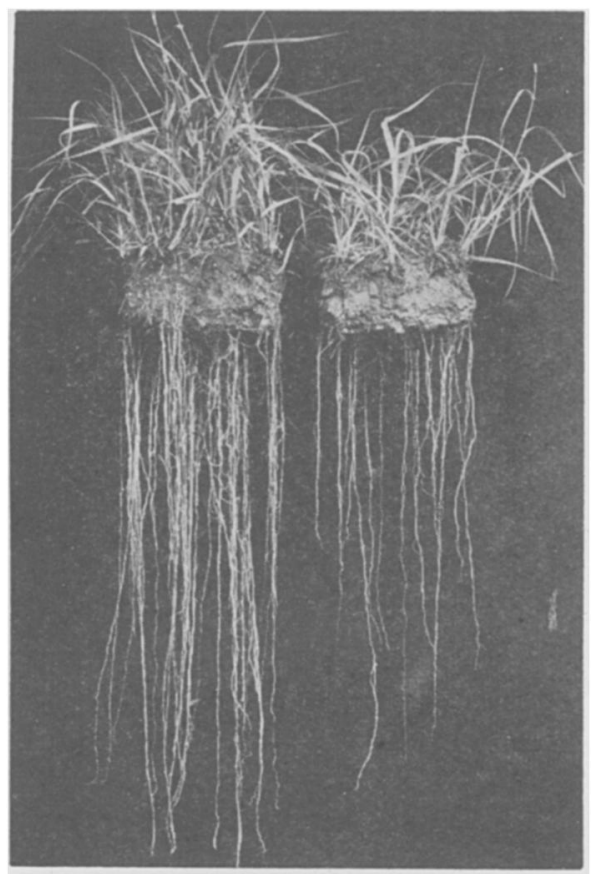

FIG. 5. Development of tops and roots of similar blocks of sod of moderately grazed (left) and closely grazed sand dropseed 28 days after transplanting the sods on June 10.

tained from a similar and adjacent pasture which had been protected from grazing for two years. The grass was dormant but soon began growth in the greenhouse. After one month much foliage, 5.5 inches tall, many stolons, and an abundance of new roots had been produced. In the less vigorous stand the grass was 3 inches tall and there were only 3 stolons with an average length of 3 inches. The control had 7 stolons with an average length of 7 inches. Roots were fewer and the working depth less than half as great on the overgrazed sod (table II).

Another pair of sods $4 \times 4 \times 4$ inches in size was furnished by Dr. F. W. Albertson, from heavily grazed and moderately grazed ranges, respectively, at Hays in west central Kansas. The soil was a compact very fine sandy loam. Between April 20 and June 3 the moderately grazed sod produced 3.10 grams of tops, and roots 17.5 inches long which weighed
1.11 grams. Production from the sod with greatly reduced vigor was only 0.51 gram; roots were only 8 inches long and weighed 0.08 gram. Here again the stolons were fewer and shorter on the weakened plants.

A third pair of sods of buffalo grass was taken from another lowland pasture near Lincoln. Most of the pasture was overgrazed but one sod was from a local area surrounded by the much less palatable western wheat grass and the buffalo grass here had escaped grazing for at least a year. The transplanted sods were left undisturbed from June 6 to July 8. There was a much greater difference in development of tops, which were more than twice as heavy in the ungrazed sample, than in development of roots. The roots, however, were considerably shorter and their dry weight 28 per cent less (table II and

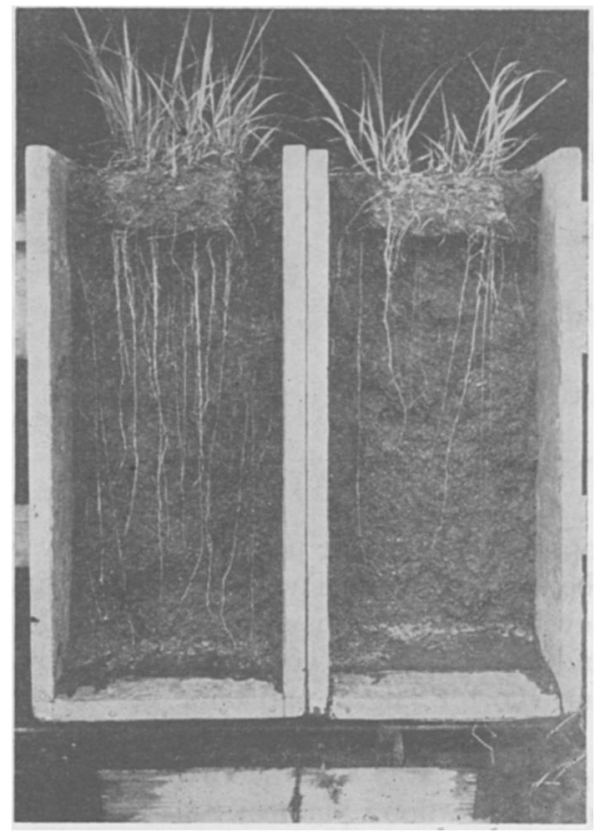

Fig. 6. Bunches of side-oats grama 28 days after transplanting the blocks of sod. The left one, with many roots 20 inches deep and abundant stems, had been only moderately grazed. The bunch with low vigor resulting from close grazing produced less than half as much dry weight of tops or roots. 
fig. 7). Differences in development of stolons were pronounced. On the overgrazed plants there were 18 with a total length of 6 feet; the ungrazed control produced 38 with a total length of 26 feet.

Blocks of buffalo grass sod were also taken from the pasture on loess soil at Kearney. Height of foliage, about a month after transplanting on June 10 , was only 1.5 inches greater on the sod moderately grazed than on the closely grazed one. But dry weight of foliage was twice as great, there were more and longer stolons, the working depth of roots was 6 inches greater, and the dry weight of roots was more than four times as great (table II).

Two samples of blue grama were taken from a pasture on the flood plain of Salt Creek where much experimental work has been done and where the cover has been under continuous observation. One sample was from the part of the pasture

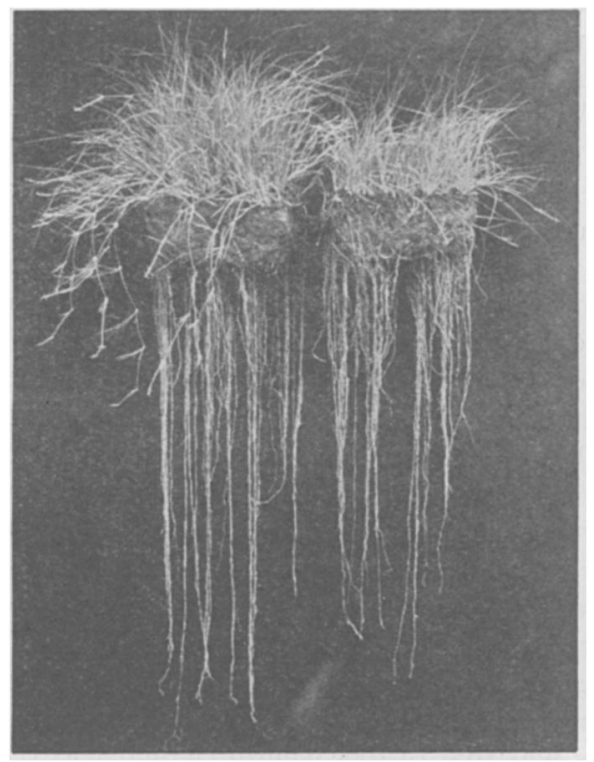

FIG. 7. Plant production from closely grazed sod of buffalo grass (right) and ungrazed sod during a period of 32 days. The yield from the ungrazed sod is more than twice as great. There are also twice as many stolons with a total length four times as great as those on the grazed grass.

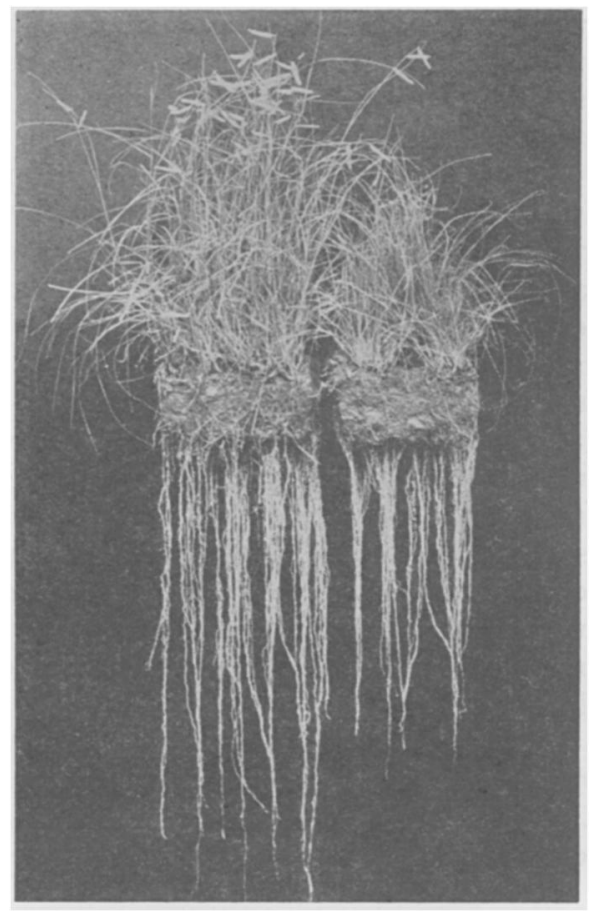

Fig. 8. Ungrazed (left) and grazed sods of blue grama. The new crop of foliage and roots developed in 7 weeks. The more vigorous plants produced 27 flower stalks, the heavily grazed ones only 3 .

where the grass had been repeatedly grazed to a height of an inch. The other had been protected by a surrounding stand of western wheat grass. The sods were transplanted on March 27 and examined on May 14. Differences in height of foliage and abundance of flower stalks as well as in root development are shown in figure 8. Weight of tops was almost twice as great on the protected sod. Both working depth and maximum depth of roots were also much greater (table II).

Smaller blocks of sod were selected in the mixed prairie at Hays, Kansas. They were $4 \times 4 \times 4$ inches. One was from a moderately grazed and one from an overgrazed range. The first sod, 44 days after planting (on April 20), had produced a thick stand of stems; the less vigorous stand of the second was sparse and 1.5 inches shorter. Yield of forage was re- 
duced to less than one-fourth as much as the control. As usual, roots were fewer, much shorter, and greatly reduced in weight (table II).

A third pair of sods of blue grama, $7 \times 7$ inches and 4 inches deep, was taken from the upland pasture at Kearney. One had a basal cover of 85 per cent and appeared in good condition, although the forage had been removed closely late in fall. The second was from a portion of the pasture repeatedly grazed to an inch or less. Yield from the weakened, overgrazed sod was only 36 per cent as great as that from the other one. Working depth of roots was reduced 6 inches and dry weight of roots was only one-fifth as great as that of the moderately grazed plants (table II).

A single pair of sods of big bluestem was selected from a lowland pasture near Lincoln. The native prairie species were being displaced by Kentucky bluegrass,

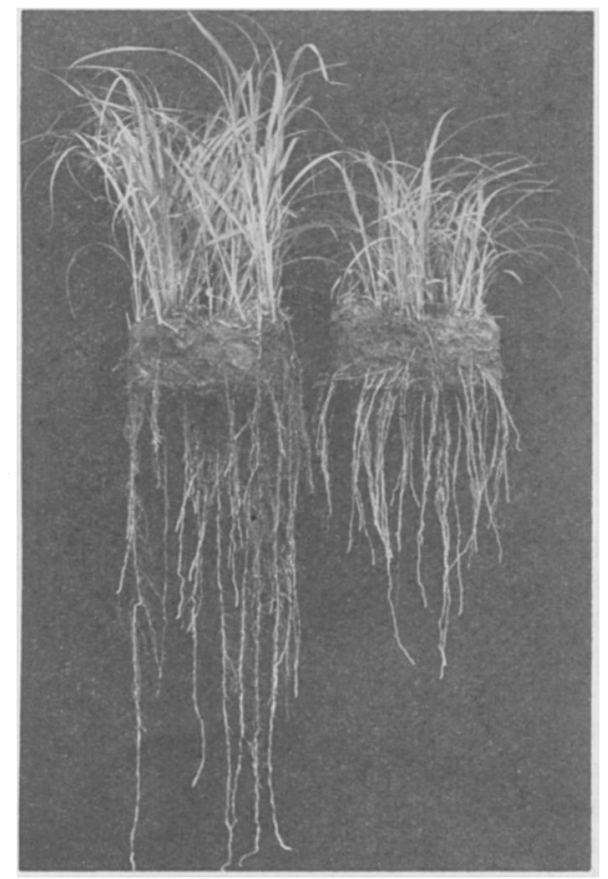

Fig. 9. Plants of closely grazed (right) and moderately grazed big bluestem. The roots on the less vigorous plants are much finer and very poorly branched as well as shorter. because of too early and too close grazing. On May 24 the ungrazed new growth was only 2 inches tall but that of a sod which had been protected by surrounding western wheat grass was 4.5 inches high. Forty days after transplanting the new tops and roots were examined (fig. 9). Weights of tops were 7.11 and $1.99 \mathrm{gm}$. and those of roots 1.71 and $0.52 \mathrm{gm}$., respectively (table II).

- Tall dropseed was obtained from the lowland experimental pasture near Lincoln on May 24. Two bunches were selected and sods of the usual size and depth were taken. The stubble of one bunch showed that it had been grazed high, 12.5 inches, the preceding year, and two-yearold debris in it indicated similar if any grazing earlier. The other bunch hacl been grazed the preceding year to 4 inches. The slender leaves, now 10 inches high, indicated weakened vegetation when compared with the taller and broader leaves in the bunch grazed high. After 40 days the new tops were 10 to 14.5 inches high, the stems being much thinner in the less vigorous bunch (fig. 3). Weight of foliage was only about a third that of the moderately grazed bunch. The root system below the sod was also proportionately smaller (table II).

A bunch of little bluestem was obtained from a pasture which had been grazed heavily to a height of an inch during a period of two years. On May 14 the new shoots were scattered thinly in the bunch. Over the fence and beyond the reach of the cattle a second bunch was selected from virgin prairie. It was well filled with new stems 4 inches high. After 45 days the new tops were 9.5 inches (control) and 5 inches tall, respectively. The weights were 5.58 and $1.44 \mathrm{gm}$. Difference in depth of roots was not as marked as was that of dry weight, which was 0.80 and 0.33 gm., respectively (table II).

In concluding the presentation of data, a final example will be given where not only non-vigorous and moderately vigorous plants were compared but also similar plants whose vigor apparently had not 
at all been impaired. This experiment was made the preceding year, beginning May 17. A well-filled bunch of little bluestem was taken from an excellent pasture 8 miles west of Lincoln. The previous year's stubble was 6 inches tall and the new growth was also 6 inches high. The second bunch, from an adjoining good pasture, had been grazed for about 2 years. The center of the bunch was dead but a moderately thick new growth was 2 to 2.5 inches tall. This was the approximate grazing level. This bunch was slightly invaded by bluegrass. The third bunch from a much-abused pasture on similar soil was the same size, but the central part, which was 3 to 4 inches in diameter, was dead and only a few weak shoots 0.5 to 1.5 inches tall grew on the periphery of the bunch. The whole bunch had been invaded by bluegrass. The sods were transplanted without removing the tops but the shoots of bluegrass were repeatedly removed. These transplanted sods were 4 inches wide, 6 inches long, and 3 inches deep.

The new roots were exposed and the plants photographed (fig. 10) after a period of 6 weeks. The tops were 15,12 , and 6 inches in average height and the roots extended below the sods to average depths of 15,11 , and 9 inches, respectively. Weights of tops and roots are given in the legend of figure 10. Here is overwhelming evidence that overgrazing does not pay and that a rundown pasture is a poor investment.

\section{Resumé}

A survey of table II shows clearly that the production of new forage was considerably decreased in every instance where average plants of lowered vigor were compared with average plants in a good to fair condition for growth. Decrease in the dry weight of tops ranged between 32 and 84 per cent and that of roots between 28 and 94 per cent. Differences in weight of roots were often more marked than differences in either working depth or maximum depth, since roots of non-vigorous plants are more slender and more poorly branched. There was usually a considerable difference in the number of roots, those on vigorous plants being more plentiful, but this criterion is much less important than length, diameter, and degree of branching. Branching was always much more pronounced in plants with a good reserve of accumulated food.

Comparison of one species in table II with another is of little value. There were differences in the time of transplanting, in the size and depth of the blocks of soil, and in the period and conditions for growth after transplanting. Perhaps the greatest difference, however, was in the degree to which. both the control and the more weakened plants were depleted of food reserves. These range grasses make their best growth in spring or early summer. If growth is nearly completed without removal of tops, new growth after transplanting is not marked. But if development of tops has been retarded by moderate grazing or by drought then the plant may grow quite vigorously even in fall (Weaver and Albertson, '43:106).

It is believed this test for vigor is a valid one for native grasses of the midwestern range. There is some evidence, however, that Kentucky bluegrass will produce as great a growth of both tops and roots when it is regularly grazed as when it has been left to produce seed with tops intact for a year. Eastward, degeneration of bluegrass pastures has been reported when they remained entirely ungrazed (Carrier and Oakley, '14; Etheridge, '19). In one test yields of roots and tops were practically the same under close grazing and complete protection. In another the protected sods yielded less both above and below ground. Perhaps here the test of vigor should be limited to bluegrass under different degrees of grazing.

\section{Other Signs of Decreased Vigor}

Weakened plants exhibit the degree of their decrease in vigor not only in re- 


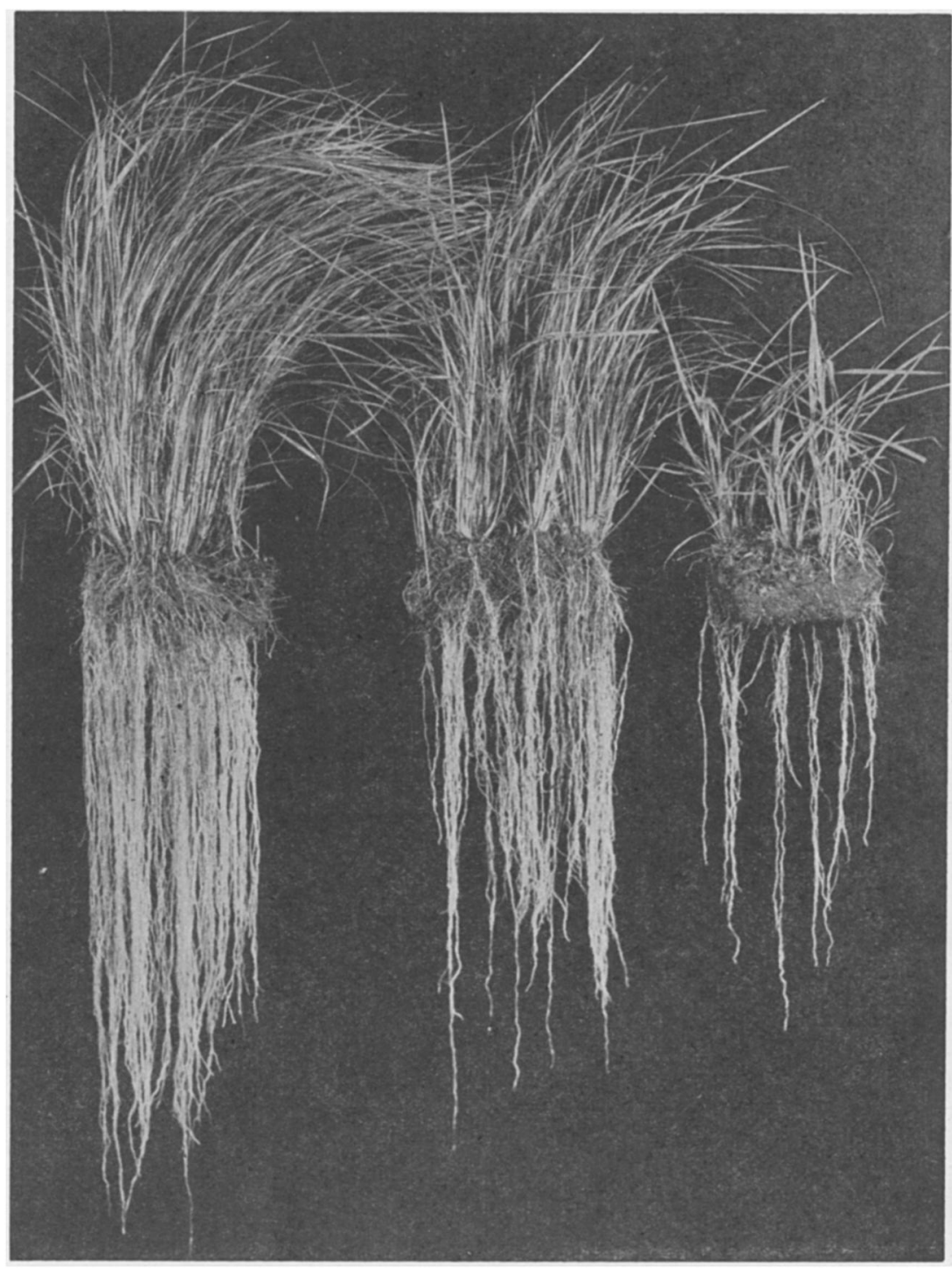

Fig. 10. Plants of little bluestem grown from sods of similar size taken from an excellent, a good, and a poor pasture. This is the new growth after six weeks. Weight of tops was $30.22,12.89$, and $1.87 \mathrm{gm}$., although there do not appear to be such great differences. "Weight of roots was $4.70,1.72$, and 0.33 grams. Roots were progressively more slender with decrease in vigor.

duced size above and below ground but also in slower resumption of growth, decrease in length and width of leaves, and in decreased diameter of roots. Several instances have been given where the weakened plants were later in resuming growth and especially where height at- tained was much less in the plants with low vigor. This, of course, is common knowledge to trained range investigators. A degree of delayed growth and slower development was observed in every instance in the pairs of transplanted sods (fig. 11). 


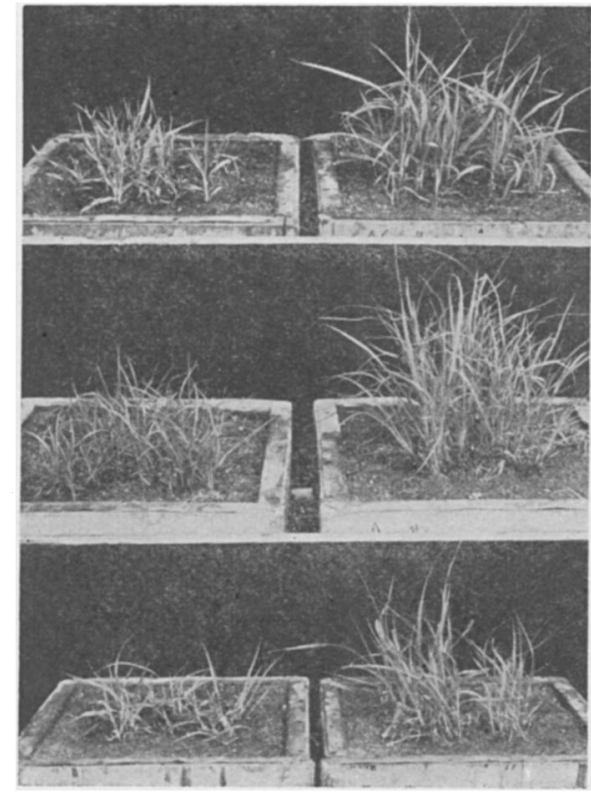

FIG. 11. Less vigorous sods (left) due to early, continuous, and heavy grazing, and more vigorous ones (right) where the impact of grazing was less pronounced. The tops are all 27 days old and are samples of big bluestem (upper), little bluestem (center), and side-oats grama (lower). Casual inspection shows that there is also a marked difference in length and width of leaves. Photo June 10.

The average width of leaves and average diameter of the roots were measured on several pairs of sods already described. Width of large leaves was obtained with a millimeter ruler but that of smaller ones and all diameters of roots were measured under the microscope to the nearest hundredth $\mathrm{mm}$. (table III). The decrease in average width of leaves ranged between 15 and 41 per cent. Similar decreases in roots ranged between 13 and 39 per cent. In every instance the plants with decreased vigor were smaller in both width of leaf and diameter of root, as well as in length of leaves. Frequently all of the leaves of the weakened plants were smaller. In the blue grama in table III, for example, the leaves of the more vigorous plants ranged in width between 2.17 and 3.12 $\mathrm{mm}$. but those of the much weakened ones between 1.44 and $1.90 \mathrm{~mm}$. These data agree with similar measurements made in the field. Where western wheat grass, for example, had been grazed to above 12 inches the previous year, the average width of 100 leaves on June 4 was 3.55 mm. Width of a similar number of leaves of plants nearby, where grazing had been at 5.5 inches the preceding year, was only $2.54 \mathrm{~mm}$. or 28 per cent less.

Production of flower stalks occurred in some of the more vigorous groups of transplanted plants even within the few weeks of the experimental planting. Delayed flower stalk production, decrease in number and size of inflorescences, and low vitality of the seed produced are all further indicators of low vigor. Weakened plants with poor root systems are much more subject to winter killing as well as to drought (Biswell and Weaver, '33). In fact, drought for them actually becomes more and more imminent since their competitors, including weeds, increase in vigor, using more and more of the available water as they become larger.

TABLE III. Average width of the third leaf (near its middle) from 20 stems and average diameter of 20 roots with cortex intact 4 inches below the sod. Decrease in size is given in nearest per cent. All samples were taken at random. (Numbers of any pair of sods correspond to their numbers in table $I I$ )

\begin{tabular}{|c|c|c|c|c|c|}
\hline \multirow{2}{*}{ Species } & \multirow{2}{*}{ Pairs } & \multicolumn{2}{|c|}{ Leaves } & \multicolumn{2}{|c|}{ Roots } \\
\hline & & $\begin{array}{l}\text { Ave. } \\
\text { width }\end{array}$ & $\begin{array}{l}\text { Per cent } \\
\text { decrease }\end{array}$ & $\begin{array}{l}\text { Ave. } \\
\text { diam. }\end{array}$ & $\begin{array}{l}\text { Per cent } \\
\text { decrease }\end{array}$ \\
\hline $\begin{array}{l}\text { Side-oats } \\
\text { grama }\end{array}$ & $\begin{array}{l}1 \\
2\end{array}$ & $\begin{array}{c}m m . \\
6.9 \\
5.2\end{array}$ & 25 & $\begin{array}{r}m m . \\
1.07 \\
.65\end{array}$ & 39 \\
\hline $\begin{array}{l}\text { Side-oats } \\
\text { grama }\end{array}$ & $\begin{array}{l}3 \\
4\end{array}$ & $\begin{array}{l}4.5 \\
3.8\end{array}$ & 16 & $\begin{array}{l}.60 \\
.52\end{array}$ & 13 \\
\hline $\begin{array}{r}\text { Buffalo } \\
\text { grass }\end{array}$ & $\begin{array}{l}5 \\
6\end{array}$ & $\begin{array}{l}1.7 \\
1.2\end{array}$ & 29 & $\begin{array}{l}.53 \\
.44\end{array}$ & 17 \\
\hline $\begin{array}{l}\text { Blue } \\
\text { grama }\end{array}$ & $\begin{array}{l}1 \\
2\end{array}$ & $\begin{array}{l}2.7 \\
1.6\end{array}$ & 41 & $\begin{array}{l}.65 \\
.45\end{array}$ & 31 \\
\hline Big & 1 & $\begin{array}{l}6.1 \\
5.2\end{array}$ & 15 & $\begin{array}{r}1.29 \\
.84\end{array}$ & 35 \\
\hline $\begin{array}{l}\text { Tall } \\
\text { dropseed }\end{array}$ & $\begin{array}{l}1 \\
2\end{array}$ & $\begin{array}{l}4.1 \\
2.9\end{array}$ & 29 & $\begin{array}{l}.62 \\
.49\end{array}$ & 21 \\
\hline
\end{tabular}




\section{Death of Roots Accompanying Fre- QUent Removal of Tops}

Bluestem grasses were taken from the prairie in early spring as soon as the soil had thawed and before any visible growth had occurred. Six large blocks of sod of big bluestem and 6 large bunches of little bluestem were removed to a depth of 4 inches. The dead tops showed clearly that these vigorous plants had produced an excellent yield the preceding year. Sods of big bluestem were trimmed to an exact size of $12 \times 4$ inches by 3 inches deep and then cut into halves so that each member of a pair was 6 inches long. The blocks of little bluestem were trimmed to $8 \times 6$ inches and 3 inches deep and then were split in half so that each member of a pair was also 6 inches long and 4 inches in width. After removing the old tops, the soil blocks were transplanted into loam soil intermixed with one-third sand. Boxes $8 \times 8$ inches and 8 inches deep were used. This was done on March 30. During the following month new tops developed and by April 30 an abundance of new roots extended 3 to 5 inches below the sod.

The soil was washed away from the sods and roots, after which the roots were kept constantly moist during a process of banding. Following the methods of Weaver and Zink ('46), a small band of very thin and pliable tin about $10 \mathrm{~mm}$. long and $4 \mathrm{~mm}$. wide was placed around each root (fig. 12). The sods were then transplanted in galvanized iron cans 18 inches in diameter and 22 inches deep. A removable band of galvanized iron 6 inches wide was inserted to a depth of 2 inches within the top of each can. The transplanting was done so carefully that the roots were apparently unharmed. First the containers were filled with moistened and firmed soil to within 12 inches of the top of the band. While one investigator held the sod in such a position that three blocks could be placed in a container, the other carefully poured in dry soil mixed with sand until the extended

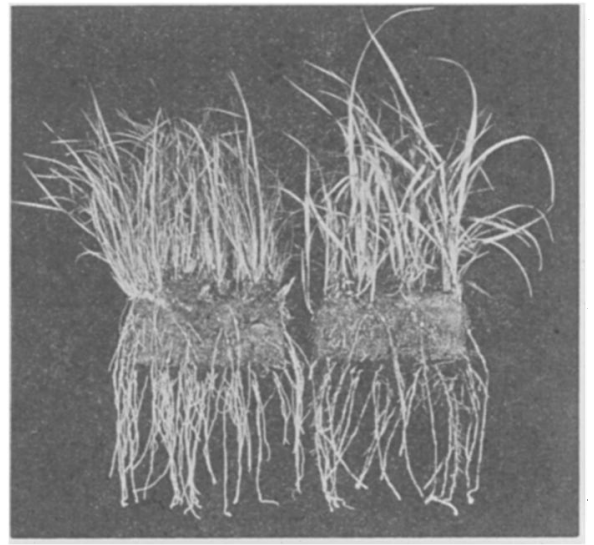

Fig. 12. A block of little bluestem (left) and big bluestem (right) showing the growth of tops and roots one month after transplanting. Each root has been banded.

roots were entirely surrounded with soil. This was immediately watered and more dry soil added until soil was finally, after repeated wetting, at the same height as the top of the sod. In this manner 3 halfbunches of little bluestem were placed in one container and the other halves of the same bunches in another. Likewise of the three original pieces of big bluestem sod half of each piece was transplanted in one container and half in another.

Banding had been done on a damp, cloudy day and this condition prevailed for several days thereafter. Transplanting did not result in wilting and growth continued apparently unchecked. After 4 days one container with little bluestem and one with big bluestem were selected by lot and the grasses were clipped at a height of 2 inches. Clipping was repeated at intervals of 7 to 10 days until a seventh clipping was made on July 3 . Both species regained a height of 6.5 to 7.5 inches at each clipping except the last, when they were 1 to 1.5 inches shorter. The controls gained steadily, little bluestem attaining an average height of 20 inches and big bluestem 25 inches when the sods were removed on July 11,10 weeks after the second transplanting.

Stem counts had been made on June 23 
before the sixth clipping. The control sods of little bluestem had 434 stems. So many stems on the clipped plants failed to regenerate that only 255 had new leaves. This decreased to 115 at the last clipping. Similar data for big bluestem were 102 and 95 stems on June 23, but only 58 on July 3 . Clearly the tops had decreased greatly in vigor. This was further indicated in little bluestem by very little tillering, narrow leaves, and much dead stubble after June 13 . The plants also became light green in color. The color of big bluestem remained good, but the leaves were narrower, and tillering gradually declined.

Loss of vigor was also accompanied by death of roots. Upon washing away the sandy soil after removing the top extension, differences in numbers of roots were found to be pronounced (fig. 13). While the control sods of big bluestem lost by death only 2 of the 79 banded roots, the loss on the clipped sods was 14 of the 75 banded, or 19 per cent. Losses in clipped little bluestem were greater. Although only 1 root of the 100 banded on the controls died, 44 of the 102 (43

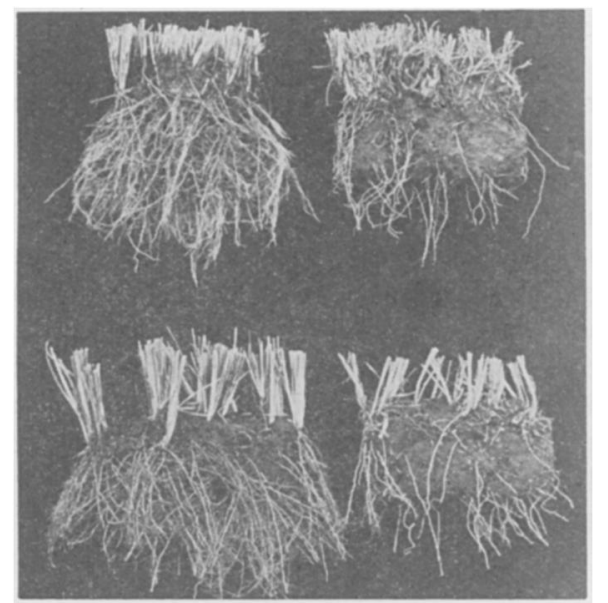

FIG. 13. Control blocks of little bluestem and big bluestem (left) and companion blocks of the pairs (right) from which the tops had been repeatedly clipped. Not only have many of the original roots of the clipped plants died but few new roots have developed. Only the upper portion of the root system is shown. per cent) on the clipped plants succumbed. Total number of roots per sod in figure 13 is 241 on control little bluestem but only 53 where the tops were clipped. Similar figures for big bluestem are 228 and 40 .

The roots on the control plants were of much greater diameter, they had a greater capacity for food storage, and the development of lateral branches was far better than that of the clipped plants.

\section{Discussion}

The direct examination of roots of grass on the range to ascertain the degree of deterioration is difficult, tedious, and not entirely satisfactory. Intermixed with the living or half-dead roots are others in various stages of decomposition. Dead roots may completely disappear after only 2 to 3 years (Weaver, '47). Moreover, roots of other plants are often encountered. Satisfactory photographs of details are extremely difficult and one must usually resort to drawings.

The conditions of the root systems of plants of blue grama with high and low vigor and those much depleted have been shown by Flory and Trussell ('38). These were representative individuals grown in the blue grama-galleta-sage brush range type in northern New Mexico. The rainfall was 10 to 18 inches and the deep soil presented a mature profile. Roots of plants in full vigor had a general working level of 18 inches. Although some extended to a depth of 2.5 to 3.5 feet, the major portion of the root system was in the upper 8 inches of soil. Roots of grass in low vigor had a working depth of only 6 inches; some of the deeper ones reached 1 to 1.5 feet in depth. Maximum depth of greatly weakened plants was only 0.5 to 0.75 foot, and the working depth was only an inch or two in the surface soil. Plants with low vigor occupied only one-third of the soil volume of those in high vigor, and greatly depleted ones only one-tenth as much soil. A somewhat similar sequence was found for galleta. (See also Lantow and Flory, '40.) 
The fact that good root systems do deteriorate and the roots die back from their tips has been definitely established. The senior writer assisted in the excavation of the roots of Sudan grass grown in the field under different degrees of clipping by one of his students (Peralta, '35). On July 8 , roots of the control plants were 6 feet deep. Those of plants clipped at three different periods were shallower. Those clipped at a height of 6 inches were 4 feet deep, but plants clipped at 2 inches height extended downward only 2 to 3 feet. Moreover, the last were clearly weakened and deteriorating. On August 17, roots of the control plants were approximately 7 feet deep. The others, which had now been clipped 6 times, were 5.5 and 4.75 feet deep, respectively. But the roots on plants clipped high were dead and decaying below a depth of 4 feet; those of plants clipped low were in a similar condition below 3 feet.

The change from one type of pasture to another of lower grade includes loss of vigor in some of the best-liked and most nutritious grasses. If one can read this sign of range deterioration and decrease the number of stock, defer grazing, rest the pasture, or apply other remedial measures, the range will recover and often improve. Unless changes are made, there will be a decrease in number of plants, resulting in a thinning of the stand. Accompanying the decrease in density bare soil will appear unless the open places are immediately occupied by weeds or grass of lower forage value. Moreover, the soil will become more easily eroded by wind and water.

All these things may happen so gradually that they are not obvious to the untrained observer who has not learned how to "read the range." The first principle is that healthy, vigorous climax grasses (those found in virgin grasslands) are the best competitors against weeds and inferior species and are also the ones that yield the most and best forage. Conversely, weakened plants cannot compete successfully with less desirable plants over which they ordinarily dominate. Neither do they have the root reserves nor the good root system which is necessary for a rapid response to rainfall and prompt recovery after being grazed. As long as the best plants retain their vigor despite moderate grazing, the excellent pasture will retain its high productivity, the good pasture will remain good (Talbot, '37).

One of the first objectives in range and pasture management is to maintain plant vigor (Lantow, '45). This paper offers a direct, nontechnical method of measuring vigor of range grasses. The necessary equipment is cheap and can easily be improvised. The test need be applied for only a few weeks. The new root system can be washed free of soil in about 30 minutes. It portrays the condition so vividly that, once seen, it will be long remembered by farmer, rancher, or technician. It is a method of demonstrating to the cattleman how his range looks "under the grass." It demonstrates that too close and too frequent removal of forage weakens the roots, reduces forage yields, and is not a preparation against drought. He will note that the damage is not temporary but will also decrease the next year's yield.

Various agencies are now making good progress in disseminating scientific information about grasses where it can be of immediate use. It is the purpose of this paper to present this method so that it may be used to encourage better range and pasture management. This direct method of approaching a problem of wide economic importance also enlists at once the profound interest of the college student. It is one very definite way in which plant ecology may be applied to aid in the national economy.

\section{SumMary}

The degeneration of excellent or good native pastures and ranges into medium or poor ones is always preceded by a decrease in vigor of the most nutritious and bestliked grasses. These are nearly always the climax species. Decreased vigor may 
result from overgrazing or from drought.

If this sign of range deterioration is observed and stocking rate is decreased, or grazing deferred, or the pasture completely rested, the range will usually recover and often improve.

Vigor of the vegetation, composition, and density are the most important indicators among plants as to the condition of the range. Vigor is commonly shown by the size of bunches or clumps and especially by the number of stems, absence or presence of dead centers, and partial or complete death of tufts or bunches.

An excellent test of vigor under conditions favorable for development is that of prompt renewal of growth in spring, after grazing, or after transplanting. The last permits exact measurements of heights, production of forage, and the rate of development and amount of new roots.

Blocks of sod of vigorous bluestems, needle grass, and tall panic grass were obtained from native prairie in spring before resumption of growth. They were transplanted in sandy loam soil in boxes $10 \times 10$ inches and 24 inches deep, with one removable side.

Plants which had been clipped 4 times at weekly intervals had lost much of their vigor. While all controls developed extensive root systems during 42 days, as revealed by washing away the soil, clipped plants had very few or no roots. Differences were pronounced and decrease in growth was so similar to that of continuously overgrazed grasses, that this method, somewhat modified, was employed to test the vigor of 8 species of range grasses.

Bunches or blocks of sod were selected for transplanting from overgrazed and moderately grazed pastures. The tops were removed and new tops and roots were grown during periods of 4 to 6 weeks. Sand dropseed, side-oats grama, Scribner's panic grass, buffalo grass, blue grama, big bluestem, tall dropseed, and little bluestem were tested, often in duplicate or triplicate, and from widely distant stations.
Dry weight of tops of weakened plants was 32 to 84 per cent less than that of plants which had good to fair vigor. New roots were always shorter and less branched, and dry weight was 28 to 94 per cent less than that of the controls.

Leaves of non-vigorous new tops of 6 species averaged 15 to 41 per cent narrower and average diameter of new roots was 13 to 39 per cent less. Moreover, it was ascertained by banding new roots of vigorous plants that death of roots accompanied frequent removal of tops, as in close grazing.

This test of vigor requires only 4 to 6 weeks. The new roots can be washed free of soil in 30 minutes.

\section{Literature Cited}

Bews, J. W. 1929. The world's grasses. Longmans, Green and Co. New York.

Biswell, H. W., and J. E. Weaver. 1933. Effect of frequent clipping on the development of roots and tops of grasses in prairie sod. Ecology 14: 368-390.

Carrier, L., and R. A. Oakley. 1914. The management of bluegrass pastures. Va. Agric. Expt. Sta. Bull. 204.

Costello, D. F., and G. T. Turner. 1944. Judging condition and utilization of shortgrass ranges on the Central Great Plains. U. S. D. A. Farmers' Bull. 1949.

Darland, R. W., and J. E. Weaver. 1945. Yields and consumption of forage in three pasture-types: an ecological analysis. Univ. Neb. Cons. and Surv. Div. Bull. 27.

Etheridge, W. C. 1919. Management of bluegrass pastures. Univ. Mo. Agric. Ext. Serv. Circ. 66.

Flory, E. L., and D. F. Trussell. 1938. Observation of plant competition, plant succession, plant-soil relationships, overgrazing and erosion on sagebrush areas. Soil Conserv. Service (Region 8) Regional Bull. 24, Series 3. (Mimeographed.)

Humphrey, R. R., and P. B. Lister. 1941. Native vegetation as a criterion for determining correct range management and run-off characteristics of grazing lands. Jour. For. 39: 837-842.

Lantow, J. L. 1945. Plant vigor and range production. Soil Conserv. 10: 178-180.

Lantow, J. L., and E. L. Flory. 1940. Fluctuating forage production: its significance in proper range and livestock management on southwestern ranges. Soil Conserv. 6: $1-8$. 
Peralta, F. 1935. Some principles of competition as illustrated by Sudan grass, Holcus sorghum sudanensis (Piper) Hitch. Ecological Monog. 5: 355-404.

Renner, F. G., and E. A. Johnson. 1942. Improving range conditions for wartime livestock production. U. S. D. A. Farmers' Bull. 1921.

Talbot, M. W. 1937. Indicators of southwestern range conditions. U. S. D. A. Farmers' Bull. 1782.

Weaver, J. E. 1947. Rate of decomposition of roots and rhizomes of certain range grasses in undisturbed prairie soil. Ecology 28: In press.

Weaver, J. E., and F. W. Albertson. 1943. Resurvey of grasses, forbs, and underground plant parts at the end of the great drought. Ecological Monog. 13: 63-117.
Weaver, J. E., and T. J. Fitzpatrick. 1932. Ecology and relative importance of the dominants of tall-grass prairie. Bot. Gaz. 93: 113-150.

Weaver, J. E., and T. J. Fitzpatrick. 1934. The prairie. Ecological Monog. 4: 109295.

Weaver, J. E., and W. W. Hansen. 1941. Native midwestern pastures: their origin, composition, and degeneration. Univ. Neb. Cons. and Surv. Div. Bull. 22.

Weaver, J. E., and W. W. Hansen. 1941a. Regeneration of native midwestern pastures under protection. Univ. Neb. Cons. and Surv. Div. Bull. 23.

Weaver, J. E., and E. Zink. 1946. Length of life of roots of ten species of perennial range and pasture grasses. Plant Physiol. 21: 201-217. 